\title{
Flipped v's Traditional Teaching Perspectives in a First Year Accounting Unit: \\ An Action Research Study
}

\begin{abstract}
With the need to move accounting students towards deeper learning approaches and understandings, this first cycle of an action research study sought to determine the student's perspective of the flipped learning approach. With this learning approach gaining momentum in recent times, this study focuses on a first-year introductory accounting class in an undergraduate business degree. In making changes to the learning environment, we survey students and find that there are significant differences between the flexible student, that is, students that are already exposed in a limited way to this approach, and the face-to-face student. Results indicate further action research is required if the flipped learning approach is to be considered a serious teaching and learning contender for the first-year student.
\end{abstract}




\section{Introduction}

Despite numerous shortcomings, the traditional face-to-face lecture has been and remains an integral approach to course delivery in higher education today (White et al., 2016). Over recent times however, pressure has been placed on University academics to ensure the classroom experience is a more engaged environment to increase the student learning experience (Butt, 2014; Pierce \& Fox, 2012; Bishop \& Verleger, 2013; O'Flaherty \& Phillips, 2015). This is especially true in the business field, where research has highlighted the tendency for accounting students to prefer rote surface learning strategies rather than strategies that lead to deep learning and understanding (English, Luckett, \& Mladenovic, 2004; Booth, Luckett, \& Mladenovic, 1999).

Flipped classroom teaching is a learning approach that has been gaining in popularity recently, being considered a more active student learning experience (Strayer, 2012; Richardson, Abraham, \& Bond, 2012), resulting in deeper learning (Chi \& Wylie, 2014). The philosophy behind the flipped classroom teaching methodology is that it allows instructors to teach both content and process, with Strayer (2012) defining it as a specific type of blended learning design that uses technology to "move the lectures outside the classroom and uses learning activities to move practice with concepts inside the classroom" (p. 171). The flipped classroom literature is still in its infancy (Abeysekera \& Dawson, 2015), with no clear results emerging as to its effectiveness as a teaching and learning technique, and despite claims that it is a 'student centred' approach even less of the literature has examined the approach from a student perspective. These studies include for example, Bishop and Verleger (2013), Jackling (2005a \& b), Strayer (2012), and Findlay-Thompson and Mombourquette (2014) with mixed results found. With this pedagogy gaining momentum as a valid teaching approach, it is thus timely and important to ascertain the viewpoint of students. This is especially important for first year 
students as they embark on their University studies, given that learning experiences in their first year may influence their choice of course or major in subsequent years.

Abeysekera and Dawson (2015) argue that the flipped classroom approach is currently underevaluated, calling for localised interventions at the discipline, classroom and student level. They contend that rigorous primary research will assist with increasing teacher participation, helping to ensure the necessary support from university decision-makers thereby enabling larger-scale implementation of the flipped classroom approach (p.11). With large-scale investigations rarely reported in the literature (Chiu \& Cheng, 2017; White et al., 2016), this supports the notion that more work needs to be done at the local level to enable the flipped approach to be considered at a wider level.

\section{Contribution}

This current study seeks to contribute to the literature in a number of ways. First, by conducting a localised action research study at the discipline and student level, the study contributes to the flipped learning literature through its potential in informing and improving teaching and learning practices. Further, with the flipped learning literature providing mixed results in firstyear introductory courses (for example, Mason, Shuman, \& Cook, 2013; Strayer, 2012; Du \& Taylor, 2013), this study contributes through focusing on a first-year undergraduate business degree class in an introductory accounting subject.

Specifically, we describe the changes that were made to the teaching methods and consider the first-year students' perspective towards the flipped approach by examining the students' level of engagement, and their preferences in comparing this method to the traditional teaching approach. Through the utilisation of the first iteration of an action research project, we also contribute to the dearth of literature in this area in accounting education (Curtis, 2017). Finally, 
with the recognition of the need to move accounting education to deeper learning approaches, this study seeks to provide a contribution to this discussion.

The remainder of this paper begins with a review of the literature, focusing on the learning approaches in accounting, specifically examining deep and surface approaches and the flipped learning approach. We then provide the method we utilised to incorporate flipped learning into our teaching through following an action research cycle approach. This is then followed by the results of this study, that is observing and evaluating the consequences of implementing an action research cycle, followed by making sense of and sharing the lessons learned in the discussion and conclusion. This includes discussion on the study's implications, limitations and areas for future research.

\section{Literature Review}

\section{Learning approaches in accounting}

Australian higher education enrolments have grown rapidly over recent decades with total domestic and international enrolments exceeding 1.4 million in 2016 (Department of Education and Training, 2017). From a business perspective, whilst student numbers have lost some enrolment share over time, they remain strong, having the second highest domestic enrolment share by education field in Australia (Norton, 2016).

Booth et al. (1999) identified the aim of the educational process in accounting as to achieve "high quality learning outcomes" (p. 277). This is reinforced by the establishment of national accounting learning standards, the purpose of which is "to enhance the credibility and standing of accounting as a professional discipline" (http://achievementmatters.com.au/). However, accounting education continues to draw sustained criticism as to its teaching and learning deficiencies with arguments being made that accounting graduates are not suitably equipped to 
meet employer needs (Evans, Burritt, \& Guthrie, 2010; Capellatto, 2010; De Lange \& Watty, 2011; Jackling \& De Lange, 2009). Deficiencies cited include the continued emphasis on mechanical procedural approaches, lack of generic skill development and inability of graduates to transfer academic knowledge to the workplace (Jackling \& De Lange, 2009; Leveson, 2004; De Lange, Jackling, \& Gut, 2006; de Villiers, 2010). Hall, Ramsay, \& Raven (2004) noted that a fundamental concern in accounting education is the need for students to develop life-long learning skills. To achieve this, there have been calls to move away from procedural tasks and the memorising of professional standards to a more conceptual and analytical form of learning (Jackling, 2005b), which is consistent with the top ten list of desired graduate attributes for accounting and finance recruiters across Australia (Graduate Careers Australia, 2015), as well as leading to the development of life-long learning.

Preparing accounting students for life-long learning is important as it equips graduates with the necessary skills to pursue professional development opportunities throughout their careers (Shauki \& Benzie, 2017). Specific teaching methods that have been applied in an effort to improve the learning process in accounting education include the use of case studies, role plays, group-based learning initiatives, peer and cooperative learning approaches and tasks focused on improving communication skills. What this indicates is that the learning approaches adopted may be a key factor influencing the quality of student outcomes (Hall et al., 2004; Ramsden, 1992).

\section{Deep and Surface Approaches}

There are two main learning approaches employed by students, those being 'deep' and 'surface' learning. These approaches were developed and refined in the literature in the 1970's and 1980's (Biggs, 1987; Eley, 1992; Hall et al., 2004). The deep approach is argued to lead to quality learning outcomes through development of understanding of the discipline and higher 
order skillsets, including the ability to think critically and process data at higher levels. Alternatively the surface approach is focused on completing task requirements, memorisation and reproduction of information, and maintaining components of studied materials as discrete and unrelated, with a focus on learning as acquiring knowledge merely for passing examinations, leading to poorer quality learning outcomes (Biggs, 1987, 2003; Booth et al., 1999; Eley, 1992; Sharma, 1997; Ramsden, 1992; Gow, Kember, \& Cooper 1994).

A growing body of research points to the need for deep learning approaches in accounting education, with Hall et al. (2004) considering it of vital importance to the student, accounting educators and the accounting profession. The literature also shows that students who use the deep learning approach demonstrate a tendency to "perform better as well as retain, integrate, and transfer information at higher rates than students using surface learning approaches" (Laird, Shoup, Kuh, \& Schwarz, 2008, p. 470). From an accounting discipline perspective, there are limited studies that have examined the learning process in students; for example, Chan, Leung, Gow, \& Hu (1989) found a high focus on rote surface learning:

...accountancy students have a tendency to focus on the bare fundamentals and reproduce them through rote learning rather than to organise their time and follow up all suggested readings (p. 189).

Gow et al. (1994) in a study of student learning approaches by accounting students found that students' use of the deep learning approach declined over the first year, consistent with other accounting studies finding a high focus on surface leaning (for example, Chan et al., 1989; Davidson, 2002). However, in a more recent study across time, Jackling (2005b) found significant changes in students learning approaches over the three years of an undergraduate accounting course with an increased use of the deep approach to learning. 
A small number of studies have compared learning approaches across disciplines, with Eley (1992) finding that accounting students favour the surface approach in comparison to disciplines such as biochemistry, chemistry and english literature students, consistent with results found by Booth et al. (1999) and Beattie et al. (1997). Others have questioned the singular categorisation of learning approaches altogether, with both Hall et al. (2004) and Cooper (2004) finding that rote learning can be used simultaneously with deep learning approaches. Leveson (2004) examined the link between the teaching approach within the accounting discipline and the level of influence on student learning, and found close associations between the two. One deep learning method that has been advocated as leading to improved student learning experiences is the flipped learning approach (Milman, 2012; Strayer, 2012).

\section{The flipped learning approach}

Although there is no one definition of flipped learning, the underlying premise of this pedagogy is that the traditional approach to teaching is 'flipped' or inverted by moving the teaching of in-class instruction to outside of the classroom, whilst bringing practical application into the classroom and thus providing a more active student experience. The flipped approach has gained momentum as a category of blended learning methodology: through blending traditional learning with technology-based learning, enabling traditional teaching to be transferred to videos and podcasts allowing students to view the materials in their own time (O'Connor, Mortimer, \& Bond, 2011; James, Chin, \& Williams, 2014). This then allows a greater proportion of class time to be utilised for application of the teaching materials.

There are however, limited studies that have examined aspects of the flipped learning approach that specifically benefit teaching and learning (Abeysekera \& Dawson, 2015; Tamin, Bernard, Borokhovski, Abrami, \& Schmid, 2011). Those few have found mixed results with respect to 
both the effectiveness and the students' perception of this approach. For example, Bishop and Verleger (2013) found consistent results in a review of prior year studies, noting there was a small proportion of students who strongly disliked the change to this approach, but students generally considered that the experience had a positive impact on their learning. More recent studies such as Butt (2014), Kim, Kim, Khera, and Getman, (2014), Kong (2014), Brown, Danvers and Doran (2016), Chiu and Cheng (2017) and Murray, Koziniec, and McGill (2015) found students had positive perceptions of the flipped learning approach.

However, these perceptions do not necessarily translate to students' results, and whilst anecdotal evidence suggests that student learning is improved by flipped learning (Azemi, 2013) there is very little objective evidence to support this (Bishop \& Verleger, 2013; FindlayThompson \& Mombourquette, 2014), with the literature producing mixed results. For example, in comparing student results in traditional and flipped learning environments, results have been found to be identical (Findlay-Thompson \& Mombourquette, 2014), or not adversely affecting student performance (Mason et al., 2013) whilst others have found students exposed to the flipped learning environment perform better (Lento, 2016; Marcey \& Brint, 2012; Kong, 2014). Nevertheless, the extant literature suggests that a flipped learning environment leads to deeper active learning (Gleason et al., 2011; Marcey \& Brint, 2012; Butt, 2014; Findlay-Thompson \& Mombourquette, 2014).

It has also been suggested that a flipped learning approach is inappropriate for a first-year introductory course. For example, in a survey of senior-level students, Mason et al. (2013) found that thirty-one percent of respondents thought that the flipped class was only appropriate for senior classes, with only one student considering the flipped approach suitable for a firstyear class. Similarly, Strayer (2012) compared pedagogical methods in an introductory statistics class (which included students majoring in accounting) and found that flipped classes are perhaps not the preferred design for an introductory course, arguing that many students may 
simply choose not to engage as they do not have a deep interest in the subject. When implementing a flipped approach in an introductory management accounting unit, Du and Taylor (2013) found mixed results, and argued that because this approach required students to take more responsibility for their learning, some students did not respond positively. These mixed results may also be explained by the need for students unfamiliar with the flipped learning environment to take time to adjust to the change in delivery, as was found by Zhu and Zhi (2018). Nevertheless the need for deeper learning in accounting is required, and with the flipped learning literature in its infancy, we explore this learning approach applied to a firstyear undergraduate business class.

\section{Research Method}

\section{Action Research}

Action research is defined as "a global family of related approaches that integrate theory and action with the goal of addressing important organizational, community and social issues together with those who experience them" (Coghlan \& Brydon-Miller, 2014, p. xxv). As action research has developed, two distinct streams have emerged: the social welfare tradition, which focuses on broader social change, and the British tradition, which is associated with education and improvements to educational practices (Cunningham, 2008). With respect to the latter action research was initially implemented in school situations, but has increasingly been adopted within the higher education context (Paisey \& Paisey, 2005).

A number of different definitions have been provided in an accounting education context (see Curtis, 2017), with common themes being 'reflection' and 'improvement'. Whilst action research may be conducted for many different purposes (Chandler \& Torbert, 2003), the fundamental objective of any action research is to create change (Hazelton \& Haigh, 2010). Action research is a self-reflective cycle of continuous improvement (Hand, Sanderson, \& 
O’Neil, 1996) that requires educators to be critical of their own practice, which in turn helps them to better understand their students (Paisey \& Paisey, 2005). It has been argued that action research provides a powerful means of facilitating educational reform because its combination of action and research inevitably results in a challenge of the status quo (Somekh \& Zeichner, 2009). Action research is particularly well suited to the educational environment where research is conducted on a smaller scale, as it facilitates the use of a variety of both qualitative and quantitative research methods in an environment where time and cost make alternative methods unsuitable and unmanageable (Paisey \& Paisey, 2005; McGrath \& Murphy, 2016). However, while several authors have openly encouraged the use of action research in the accounting education literature, few studies using such methodology have been published (Hazelton \& Haigh, 2010; Curtis, 2017).

In those studies that have, action research has been used for example, to increase high school students' participation in accounting work experience placements (McGrath \& Murphy, 2016), to improve accounting education practices (Kelly, Davey, \& Haigh, 2000), to incorporate sustainability into accounting curricula (Hazelton \& Haigh, 2010), and to develop research awareness in students (Paisey \& Paisey, 2003) and increased student engagement (Paisey \& Paisey, 2005). Action research has also been used to foster deep and active learning through assessment (Hand et al., 1996), and engagement with technical resources such as accounting standards and pronouncements (Paisey \& Paisey, 2005). Other avenues it has been used include for example, to increase the success rates of educationally disadvantaged students (Baker \& Logan, 2006), to evaluate student feedback (Hand \& Rowe, 2001), and explore the effectiveness of different pedagogical methods such as case-based teaching (Doran, Healy, McCutcheon, \& O'Callaghan, 2011). Student views have been sought on issues such as coursework assignments (Hand, 1997), but there appears to be no published action research on student views regarding flipped learning. 


\section{The Action Research Cycle}

The action research cycle has been represented in various ways in the extant literature and to varying degrees of complexity (for example, Cunningham, 2008; Paisey \& Paisey, 2005; Curtis, 2017). The approach we adopted is consistent with Curtis (2017) (Figure 1):

Figure 1. The Action Research Cycle (source: Curtis, 2017)

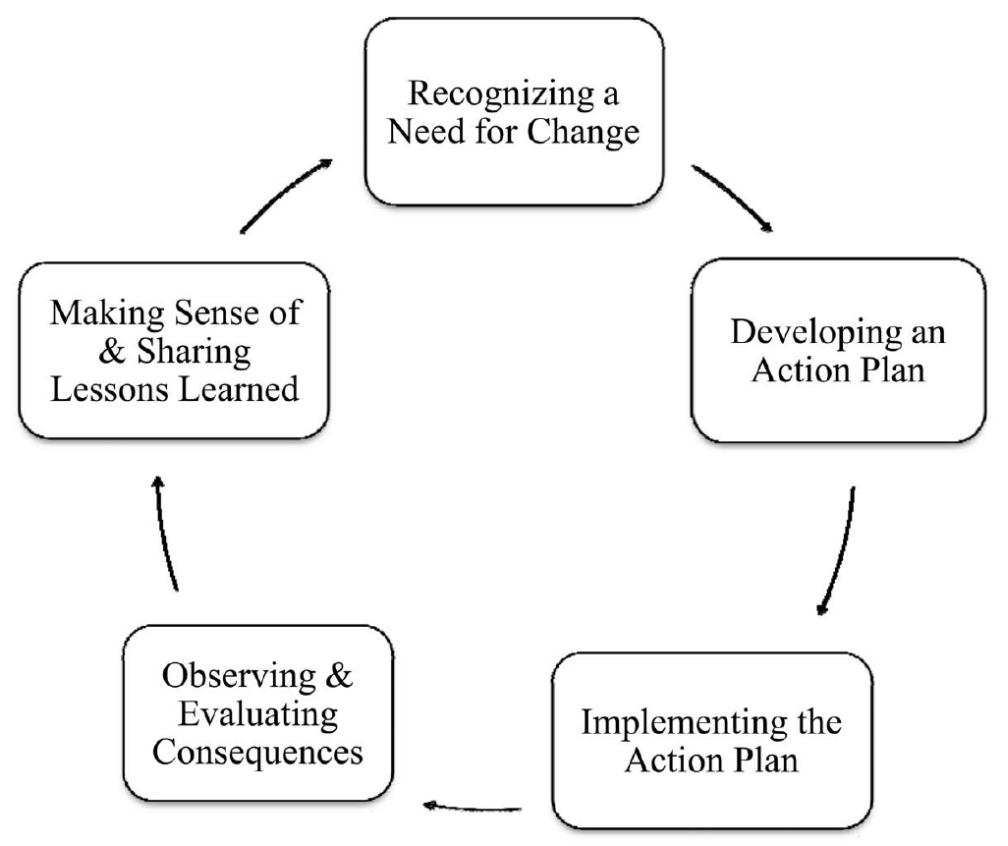

The open-ended nature of the action research cycle results in the researchers constantly evaluating, planning, executing and modifying as new information presents itself. The cycle alternates between critical reflection and action, beginning with reflection (Cunningham, 2008). Therefore, the first stage in the cycle involves reflecting on current practice (Kemmis, 2009) and recognising a need for change. In the case of the present study this involved reflecting on the increasing popularity of the flipped learning approach, yet the apparent lack of understanding on the effectiveness of this approach from a student perspective. The validity of any change to educational practices must be considered from the perspective of change desired by affected students (Hazelton \& Haigh, 2010), and when evaluating the success (or 
otherwise) of a teaching and learning method, it is important to consider the views of students (Curtis, 2017). In analysing action research practices it is important to understand the contextual conditions for action research (Somekh \& Zeichner, 2009). Therefore, the teaching approach used in the present study is outlined below.

\section{Teaching Approach}

The Tasmanian School of Business and Economics at the University of Tasmania offers the Bachelor of Business degree with Accounting as a specialisation. The degree is taught across three campuses (Hobart, Launceston and the Cradle Coast) and also as a flexible offering. A first-year undergraduate business class studying introductory accounting was chosen as the sample for this study spanning the three campus locations and separate flexible student cohort, equating to 301 students (hereafter referred to as Location H, L, CC and Flexible). Across each student cohort, the same syllabus was taught using the same teaching materials, resources and notes with an on-line learning platform available to all students.

For face-to-face students, a traditional approach to teaching was utilised, that is, a weekly twohour lecture, a one-hour workshop and a one-hour tutorial spread across the teaching week. For flexible students, the class included a partially flipped approach where students were required to listen to pre-recorded materials each week prior to attending an on-line weekly class, which involved a short overview of the lecture followed by a traditional tutorial approach.

\section{Implementing the Action Plan}

A limited change was made to the learning environment via the weekly lecture in Week 12 and is consistent with the research of Hall et al. (2004) and Gordon and Debus (2002) in indicating that limited changes to the learning environment can be effective as a means of developing a deep learning environment. Whilst Gordon and Debus (2002) reported on contextual changes made to three student cohorts from enrolment to graduation, this paper 
reports on the first iteration of a wider action research study and the response to this first change.

At the end of the week 11 classes the lecturer on each campus, and the lecturer for the flexible online student cohort, provided details of the planned change in teaching format for the following weeks' lecture to a flipped class format for both face-to-face and flexible students (with the only difference being one was taught in a physical location whilst the other in an online environment). Details included an explanation and a hand-out of what was expected of the students from a learning perspective, including the need for them to complete particular study components prior to attending class in week 12 .

Figure 2 shows the direct contact teaching approaches used: the traditional teaching approach for weeks 1-11 for face-to-face students, the partially flipped approach for weeks 1-11 for flexible online students and the flipped approach utilised in week 12 for all students. In week 12, students were required to listen to a pre-recorded standard lecture (length: 45 minutes) providing a short overview of the topic and then complete the weekly reading before attending a two-hour workshop. Whilst the extant literature suggests that shorter, rather than longer prerecorded lectures are preferred (Bishop \& Verleger, 2013), and should ideally be of no longer than ten to fifteen minutes (Mason et al., 2013), the length of the recording was necessary to cover the material required in the syllabus. With prior week's content requiring limited preparation time prior to attendance at the lecture (i.e. downloading the weekly materials), the use of the flipped class format required students to spend time in preparation prior to class.

Comparing the two teaching approaches, the traditional approach provided for a total of 4 hours contact time whilst the flipped approach provided for a total of 2 hours contact time (plus a 45-minute video prior to attending the class). By providing an active learning environment, the flipped learning literature has shown that contact time can be reduced and yet still achieve higher levels of student engagement and in some cases, improve leaning 
outcomes from traditional learning approaches (Baepler et al., 2014; Ashby et al., 2011; Haidet et al., 2004). As considered by Baepler et al. (2014), "it matters less how much time students spend in class, and much more what they do while they are in class" (p. 236).

\section{Figure 2 Direct contact teaching approach comparison}

Traditional Approach - Face-to-Face students (weeks 1-11)
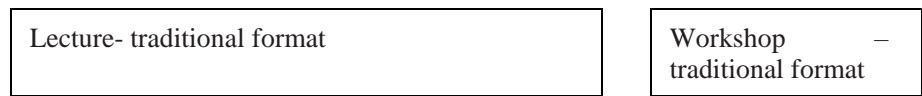

Tutorial - traditional format

Partially Flipped Approach - Flexible on-line students (weeks 1-11)

\begin{tabular}{|l|l|}
\hline Short overview of topic & Tutorial problems \\
\hline
\end{tabular}

Flipped Approach - All students (Week 12)

\begin{tabular}{|c|c|c|c|c|}
\hline $\begin{array}{l}\text { Short overview } \\
\text { of topic }\end{array}$ & $\begin{array}{l}\text { Group work- } \\
\text { Interactive style } \\
\text { questions }\end{array}$ & $\begin{array}{l}\text { Group work- } \\
\text { Presentation of } \\
\text { findings }\end{array}$ & $\begin{array}{l}\text { Group work-Case } \\
\text { study analysis }\end{array}$ & $\begin{array}{l}\text { Group Work- } \\
\text { Presentation of } \\
\text { findings }\end{array}$ \\
\hline
\end{tabular}

The two-hour workshop time was then transformed into a participatory two-hour workshop which included the lecturer providing a short summary of the topic for the week followed by interactive style questions. Students were required to work in groups for this component, with selected groups asked to present their findings to the class. To complete the workshop, students were introduced to a real-life business case study, and in their groups the students had to consider case study questions. Selected groups were then asked to present their findings to the class. The inclusion of interactive group dialogue is an important aspect of the flipped learning environment, as it helps facilitate deeper learning (Chi \& Wylie, 2014). At the conclusion of the workshop, students were invited to complete the survey (face-to-face students completed the survey in class whilst flexible students were provided with an online link to the survey via SurveyMonkey). Ethics approval for the distribution of the survey was obtained through the University of Tasmania Social Sciences Human Research Ethics Committee. 
The number of students that completed the survey totalled 126 (response rate of $41.86 \%$ ) with the number of useable surveys being 118 (representing an overall response rate of $39.20 \%$ ). The greatest response rate was from the student cohort based in Location $\mathrm{H}$ (55 students, Table 1); however, this only equated to $31.4 \%$ of the Hobart student enrolment with the largest response rate by enrolment being Location CC, (90.9\%) followed by Location L $(62.5 \%)$.

Table 1 Student Cohort Response Rates

\begin{tabular}{lllll}
\hline Student Cohort & $\begin{array}{l}\text { Number of } \\
\text { Responses }\end{array}$ & $\begin{array}{l}\text { \% of } \\
\text { Survey } \\
\text { Responses }\end{array}$ & $\begin{array}{l}\text { Total } \\
\text { Number of } \\
\text { Students }\end{array}$ & $\begin{array}{l}\text { \% of } \\
\text { Campus } \\
\text { Enrolment }\end{array}$ \\
\hline $\begin{array}{l}\text { Face-to-Face } \\
\text { Location H }\end{array}$ & 55 & 46.6 & 175 & 31.4 \\
Location L & 45 & 38.1 & 72 & 62.5 \\
Location CC & 10 & 8.5 & 11 & 90.9 \\
& 8 & 6.8 & 43 & 18.6 \\
Flexible & $\mathbf{1 1 8}$ & & $\mathbf{3 0 1}$ & \\
\hline Total & & &
\end{tabular}

\section{Survey Instrument}

Guided by prior literature, the survey instrument contained nine questions split into three sections, with the first section focused on descriptive details in the form of multiple-choice response questions (3) and one yes/no response question ${ }^{1}$. The second section focused on the level of engagement and the students' preference for the flipped style of learning using two Likert scale response questions. The two questions were split into 13 specific responses and were based on a five-point scale ranging from strongly disagree (1) to strongly agree (5). In

\footnotetext{
${ }^{1}$ For a copy of the survey, please contact the corresponding author
} 
the final section, two open-ended questions were utilised allowing students to provide additional information on the teaching and learning techniques used in the teaching unit.

Descriptive results indicated that the majority of students were in the age grouping of 20 years old or less (Table 2) representing $68.6 \%$ of respondents, followed by the $21-25$ age bracket (15.3\%) and the 26-40 age bracket (13.6\%). Respondents were evenly split between males and females $(51.7 \%$ compared to $48.3 \%)$ whilst domestic students were the dominant grouping in comparison to international students $(87.3 \%$ compared to $12.7 \%)$. Descriptive statistics were found to be representative of both face-to-face and flexible students with one exception being the age of participants. The face-to-face cohort was largely represented by the 20 years and less age group (73.6\%) whilst for the flexible cohort was largely represented by the 26-40 age group $(87.5 \%)$

Table 2 Descriptive Results for all Survey Respondents

\section{Descriptive Results Number Percent}

\section{Age of participants}

$\begin{array}{lll}20 \text { years old or less } & 81 & 68.6 \\ 21-25 & 18 & 15.3 \\ 26-40 & 16 & 13.6 \\ 41-50 & 3 & 2.5 \\ & \mathbf{1 1 8} & \mathbf{1 0 0}\end{array}$

Gender

Male

$61 \quad 51.7$

Female

$57 \quad 48.3$

$118 \quad 100$

\section{Ethnicity}

International

student

Domestic student $\quad 103 \quad 87.3$

118100




\section{Analysis Approach}

Action research projects have been criticised for lacking rigour if they fail to systematically and objectively collect data (Paisey \& Paisey, 2005). To avoid this reliability testing was conducted using Cronbach alpha testing with all coefficients above .70, indicating an acceptable reliability coefficient (Nunnaly, 1978). We analysed the results using both a quantitative and qualitative approach (SPSS software and descriptive qualitative data analysis) allowing for both an analytic and descriptive analysis, enabling the researchers to leverage the advantages of both quantitative and qualitative methods (Strayer, 2012; Kim et al., 2014).

The qualitative data analysis method used was consistent with that used by O'Dwyer (2004), involving three distinct but overlapping phases of analysis: data reduction, data display and data interpretation. All coding and sorting was completed manually allowing for better reflection upon, and recollection of the data (Anderson-Gough, 2004) with coding derived from the literature and intuitively as themes and patterns emerged.

\section{Observing \& Evaluating Consequences}

To provide an initial understanding of the level of engagement with the flipped teaching format, students were asked to indicate if they chose to complete the required tasks before attending the workshop; that is, did the students listen to the pre-recorded lecture before attending class. Of the 118 respondents, $81(73.6 \%)$ did listen to the lecture whilst for students that did not, major reasons put forward included time constraints (30.43\%) and lack of interest $(21.74 \%)$. Qualitative analysis revealed that whilst some students did not listen to the pre-recorded lecture, they did undertake other preparatory activities required by reading the lecture slides and assigned textbook chapter reading. This analysis also uncovered a third reason for not listening to the lecture beforehand with a number of students citing technical difficulties as an issue. 
For students that listened to the lecture, they were then asked to respond to a number of specific statements around this process (Table 3). Results were separated and analysed by group; faceto-face students who followed a more traditional teaching approach (group 1) and flexible students who followed a partially flipped approach (group 2) throughout the semester. The reasoning behind this categorisation was that the flexible students were already partially accustomed to the flipped approach, thus may have been more readily accepting of the flipped teaching approach in comparison to traditional face-to-face students.

\section{Table 3 Engagement with the Flipped Classroom Learning Process}

\begin{tabular}{|l|l|l|l|l|l|}
\hline Statements & \multirow{2}{*}{$\begin{array}{c}\text { Aggregate } \\
\text { Mean }\end{array}$} & $\begin{array}{l}\text { Face-to- } \\
\text { face } \\
\text { group }\end{array}$ & $\begin{array}{l}\text { Flexible } \\
\text { group }\end{array}$ & Z Level & Significance \\
\cline { 1 - 4 } & & $\begin{array}{l}\text { Level of Agreement } \\
\text { (Mean) }\end{array}$ & & \\
\hline $\begin{array}{l}\text { The pre-recorded lecture prepared me for } \\
\text { the in-class activities }\end{array}$ & 3.89 & 3.95 & 4.88 & 4.104 & .000 \\
\hline $\begin{array}{l}\text { I could see the connections made by the } \\
\text { lecturer between the on-line lecture and the } \\
\text { in-class activity }\end{array}$ & 3.83 & 3.93 & 4.25 & 1.132 & .258 \\
\hline $\begin{array}{l}\text { I was focused and not distracted whilst } \\
\text { listening to the on-line lecture }\end{array}$ & 2.95 & 2.91 & 4.13 & 2.601 & .009 \\
\hline $\begin{array}{l}\text { I enjoyed listening to the on-line lecture } \\
\text { prior to the in-class activities }\end{array}$ & 2.92 & 2.86 & 4.38 & 3.436 & .001 \\
\hline
\end{tabular}

Face-to-face students generally agreed (mean of 3.95 on a five-point scale) that the prerecorded lecture prepared them for the in-class activities, and that they could see the connections made by the lecturer in class time between the lecture and in-class activities (mean of 3.93). However, with learning of content occurring prior to class rather than in class as had been normal practice, the students neither agreed nor disagreed that they were focused and not distracted whilst listening to the lecture (2.91), nor if they enjoyed this learning activity prior to attending class (2.86). This indicates that whilst students felt they were somewhat prepared, they didn't agree that they enjoyed the learning process. 
For the flexible student grouping, they were strongly engaged through this learning process, strongly agreeing that the pre-recorded lecture prepared them for class (mean of 4.88). They could also see the connections between the materials and the in-class activity (4.25), they were focused (4.13) and enjoyed the pre-learning process (4.38). In comparing the results of the two groups via Mann-Whitney U Testing, three of the four statements were found to be significantly different (Table 3) with the flexible students agreeing at higher levels with the statements in comparison to face-to-face students. This is consistent with the proposition that flexible students, being more familiar with online learning, may find it easier to adapt to a flipped mode of delivery. Post-hoc comparisons were also conducted to examine for differences between student cohorts, with all three locations ( $\mathrm{H}, \mathrm{L}$ and $\mathrm{CC})$ revealing significantly lower differences for level of enjoyment in comparison to the flexible cohort whilst for student preparedness, only locations $\mathrm{H}$ and $\mathrm{L}$ recorded significantly lower differences to the flexible cohort.

The qualitative analysis revealed that both groups of students (face-to-face and flexible) found the flipped teaching method to be useful as it required them to undertake the required reading prior to attending class, although it must be noted that engagement with the reading activity was self-reported in the survey instrument. Whilst flexible students appeared to be more comfortable with the flipped learning environment, one noted that:

Knowing I had to participate made me prepare beforehand. I got more out of the session than previous weeks as I had completed the reading and listened to the online lecture. For me, knowing I 'have to' do the preparation makes a real difference, as it is hard staying committed as a distance student!

The qualitative analysis also revealed that students who preferred the traditional mode of delivery were the face-to-face students, with one noting: 
The lectures at Uni are better as they are more interactive. There are also less distractions at Uni as opposed to home.

However, several of the face-to-face students noted that they liked to watch the pre-recorded lecture after undertaking the in-class activities. Whilst some students indicated that they actively engaged with the online lectures by pausing and rewinding the recordings (Chi \& Wylie, 2014) there is also a risk of listening to online lectures being a very passive activity, and consistent with Toto and Nguyen (2009) some students indicated that 'it was very easy to lose concentration'.

Students were then asked to respond to a number of statements regarding their engagement around the participatory nature of the flipped learning process (Table 4). Face-to-face students were not in strong agreement or disagreement with any of the statements whilst the mean scores for flexible students were all higher than face-to-face, with means ranging from 3.75 to 3.88 .

\section{Table 4 The Flipped Classroom Learning Experience}

\begin{tabular}{|l|l|l|l|l|l|}
\hline Statements & \multirow{2}{*}{$\begin{array}{l}\text { Aggregate } \\
\text { Mean }\end{array}$} & $\begin{array}{l}\text { Face-to-face } \\
\text { group }\end{array}$ & Flexible group & Z Level & Significance \\
\cline { 3 - 5 } & 3.61 & 3.60 & 3.75 & .343 & .732 \\
\hline $\begin{array}{l}\text { I found this learning } \\
\text { approach more participatory } \\
\text { in comparison to previous } \\
\text { teaching weeks }\end{array}$ & & & 3.88 & 1.251 & .211 \\
\hline $\begin{array}{l}\text { I want a more interactive } \\
\text { environment between } \\
\text { students and lecturers in class }\end{array}$ & 3.40 & 3.37 & 3.88 & 1.966 & .049 \\
\hline $\begin{array}{l}\text { I feel comfortable } \\
\text { contributing to discussion } \\
\text { using this learning approach }\end{array}$ & 3.28 & 3.24 & & & \\
\hline
\end{tabular}

In comparing the two groups, one statistical difference found was flexible students felt more comfortable in contributing to discussion in comparison to face-to-face students $(\mathrm{z}=1.966$, $\mathrm{p}=.049$ ). The qualitative analysis suggested that this may be due in part to the nature of the venues in which face-to-face classes were held, being traditional tiered lecture theatres. Of 
those students who indicated that they wanted further interaction (all of whom were face-toface), the majority described the venue as being an impediment. For example, it was suggested that 'a venue with tables for smaller groups to sit at and discuss the topic would have been more beneficial', and that it was '[h]ard to talk in front of a large audience'. It was also noted that it was '[h]arder to motivate students to engage in a large lecture environment', and 'too easy not to participate in the activities'. These results concur with those of Chiu and Cheng (2017) who found student-centred learning spaces provide better environments for conducting active learning pedagogies in comparison to traditional classrooms.

The students were then asked to consider their preference to the flipped learning style in comparison to the traditional approach (Table 5). Whilst it is noted this was the first cycle as part of a wider action research study, it does help to provide a preliminary viewpoint for first year business students. For both student groups, there were inconclusive results to support or reject the flipped learning approach. For face-to-face students, they neither agreed nor disagreed with the statements that they learnt more (mean of 3.07) nor found the classes more enjoyable than the traditional approach (3.45), or that they would attend class more frequently if the flipped learning approach was implemented throughout the unit (3.22). The students were also unsure if the flipped approach suited them better (3.03). In the qualitative analysis, students indicated that whilst they found the subject matter for that particular topic interesting, they 'would worry how the weeks with more content could be delivered in this format' and were 'unsure whether this will help [them] in the exam'. 
Table 5 Comparing the Flipped Classroom to the Traditional Teaching approach

\begin{tabular}{|l|l|l|l|l|l|}
\hline Statements & \multirow{2}{*}{$\begin{array}{l}\text { Aggregate } \\
\text { Mean }\end{array}$} & $\begin{array}{l}\text { Face-to-face } \\
\text { group }\end{array}$ & $\begin{array}{l}\text { Flexible } \\
\text { group }\end{array}$ & Z Level & Significance \\
\cline { 3 - 5 } & Level of Agreement (Mean) & & \\
\hline $\begin{array}{l}\text { I am confident about my ability to } \\
\text { address this topic on the final } \\
\text { examination using this learning approach }\end{array}$ & 3.51 & 3.47 & 4.00 & 1.709 & .087 \\
\hline $\begin{array}{l}\text { I feel I have learnt more about this topic } \\
\text { in using this learning approach }\end{array}$ & 3.16 & 3.07 & 4.88 & 4.282 & .000 \\
\hline $\begin{array}{l}\text { I found the class session more enjoyable } \\
\text { in comparison to previous teaching } \\
\text { weeks }\end{array}$ & 3.44 & 3.45 & 3.38 & .455 & .649 \\
\hline $\begin{array}{l}\text { I would attend the classes more regularly } \\
\text { if the flipped learning approach was } \\
\text { adopted }\end{array}$ & 3.24 & 3.22 & 3.50 & .773 & .439 \\
\hline $\begin{array}{l}\text { I found the flipped learning approach } \\
\text { suited me better, in comparison to } \\
\text { previous weeks }\end{array}$ & 3.08 & 3.03 & 3.88 & 2.406 & .016 \\
\hline
\end{tabular}

For the flexible student cohort, they strongly agreed they had learnt more about the topic using the flipped approach (4.88) and were confident in their ability to address the topic in the exam (4.00). However, flexible students enjoyed the on-line classes less than face-to-face students (3.38), but felt if this learning approach was adopted, they would attend the on-line classes more regularly (3.50). The flexible cohort also considered the flipped approach suited them more (3.88) in comparison to the face-to-face students. In comparing the two groupings, two statistical differences were noted with the flexible students indicating that they learnt more using this approach $(\mathrm{z}=4.282, \mathrm{p}=.000)$ and the teaching style suited them more $(\mathrm{z}=2.406$, $\mathrm{p}=.016$ ). No significant differences were found between the face-to-face student cohort groupings $(\mathrm{H}, \mathrm{L}$ and $\mathrm{CC})$ in conducting post-hoc comparison testing.

\section{Making Sense of \& Sharing Lessons Learned}

It is currently recognised that accounting graduates are not meeting employer's expectations, with a growing body of literature highlighting the lack of life-long skill development with a focus on mechanical procedural approaches. The deep learning approach is advocated by many as a leading method in helping to improve student learning experiences (Hall et al., 2004; Booth 
et al., 1999). In undertaking the first cycle of this action research study, we applied the flipped learning approach to provide initial evidence of a first-year accounting student's experience, contributing to the flipped learning literature at a localised level as a form of deep learning approach.

After observing and evaluating the consequences of implementing the action plan, the results suggest that flexible students may find it easier to adapt to the flipped learning approach than face-to-face students. In particular, the results indicated that there was a high take up of task completion by all students prior to attending the class, whether that be listening to the prerecorded lecture or other preparatory activities such as reading the lecture slides or assigned textbook chapter readings. However flexible students were found to be more engaged with the flipped learning approach than face-to-face students through the learning process, from the initial point of preparation to attending class to engaging in class activities within the workshop. This may be due to flexible students being more readily accepting of the flipped teaching methodology as they were already partially accustomed to this approach, and prior research suggests that it takes time for students to adapt to the flipped learning environment (Zhu \& Xie, 2018).

However, with the results of the qualitative analysis indicating that flexible students required additional preparation that had to be completed prior to class, this highlights these students still had to make necessary changes to accommodate changes in teaching method. The results may also point to other factors such as age with the flexible cohort being represented by more mature students in comparison to the face-to-face cohort. Arguably mature aged students may have different motivations for undertaking university study to those continuing straight from pretertiary education, and by mode of enrolment flexible students have shown a predilection for autonomous study, possibly making them more amenable to the self-directed learning required in the flipped environment. With prior research indicating a preference by mature students for 
deep approaches to learning (Duff, 2004), the next cycle of the action research will need to determine the impact, if any of this factor.

Flexible students also indicated their preference for the flipped learning approach over face-toface students. They felt they had learnt more and this teaching style suited them better but enjoyed the class time less than in previous weeks. In contrast, face-to-face students were unsure if the flipped approach suited them better than the traditional approach and were worried about how this form of teaching would help them in the exam, especially for topics that were more 'numbers' driven. Consistent with the prior literature this is indicative of a preference to an exams-driven surface learning approach, rather than an approach consistent with deeper learning.

With these results indicating differing levels of support for the flipped approach, appropriateness of this form of teaching to a first-year students' course needs to be considered. The results highlight the need for prior exposure to this learning approach especially for the face-to-face students in this study, whether that be in the form of induction or orientation processes developed as part of the teaching unit to ensure students understand what is expected of them. With the literature questioning the relevance of the flipped approach in a first-year course, this points to the need for a wider encompassing approach at the first-year level is required to bring about change in the teaching and learning environment.

The results also suggest the need for appropriate infrastructure and resourcing at the higher institution level if flipped learning is to be implemented on a larger scale. This was evidenced through the qualitative analysis revealing the traditional tiered-seating lecture theatres not considered appropriate by face-to-face students in using the flipped learning approach. Interactive dialogic engagement is a vital component of deep learning (Chi \& Wylie, 2014), and thus the physical learning environment of the student needs to be carefully designed for 
student interaction and engagement. However, without adequate support at the institutional level, any change to the learning approach can only be achieved at a superficial and short-term level. Thus, for real change to occur within the classroom, institutional support is a necessary factor to ensure the provision of an active and deep learning experience for first year students. This is something to work towards in subsequent cycles as we move from practical to emancipatory action research to eliminate structural impediments to change (Curtis, 2017).

As with most research, this study is not without its limitations. With the focus of the first cycle of this action research study limited to the change made to the teaching approach in Week 12, the generalisability of the results are constrained due to the potential impact of the way the students perceived and approached the change in delivery. However, the purpose of action research is not to generalise, given that the results are specific to the research setting and cannot be generalised to other settings (Cunningham, 2008; Curtis, 2017). Rather, efforts to reform accounting education through action research have led to localised pockets of innovation (Curtis, 2017), and by sharing our sense-making and lessons learned from action research we contribute to the knowledge and learning from multiple local sites (Somekh \& Zeichner, 2009). In this way limited local experiences interact with each other to establish greater waves of development (Gustavsen, 2008), which is why sharing the outcomes of action research, usually through publication in journals such as this one is so important for effective education reform.

Whilst it could be argued that the results obtained in this study may have been from a novelty effect in introducing a single change to the curriculum, the novelty literature highlights that this approach "substantially increases the amount and depth of information processes undertaken by individuals" (Burke and James, 2008, p. 279-280). With the flipped learning approach stimulating more active learning, leading to a deeper learning environment (Strayer, 2012; Chi \& Wylie, 2014), the challenge then becomes if the novelty effect is indeed a factor 
in this study, accounting educators need to ensure this effect does not wear off (de Lange, Suwardy \& Mavondo, 2003).

This study provides a contribution to the literature by providing an initial exposure to flipped learning at a first-year level, recognising the need to move accounting education to deeper and more active learning approaches. With a number of face-to-face students having their first exposure to the flipped approach, future research will need to build on this first iteration as part of a larger action research study providing further exposure to this form of teaching for this student cohort. This may provide clarification as to whether the difference found between the flexible and face-to-face cohorts in the present study were due to greater exposure to the flipped learning environment, or other factors such as the average age of the cohort, size of the teaching group or even the weekly topic.

Furthermore, any propositions regarding differences between the flexible and face-to-face students need to be considered with the lower response rate of flexible students in mind, particularly in terms of the possibility of self-selection bias. A further possible limitation of this study was the use of different teaching staff across each location but this effect was minimised, as previously noted by utilising the same teaching materials, resources and notes across all student cohorts. These initial findings also indicate that subsequent action research cycles will need to gauge student perceptions at a broader level and possibly on a longer-term scale, and that other aspects of accounting education should be considered such as the impact of the flipped learning experience on student assessment and performance.

\section{References}

Abeysekera, L., \& Dawson, P. (2015). Motivation and cognitive load in the flipped classroom: definition, rationale and a call for research. Higher Education Research \& Development, 34(1), 1-14. 
Adler, R.W., \& Milne, M. (1997). Improving the quality of accounting students' learning through action-oriented learning tasks. Accounting Education, 6(3), 191-215.

Anderson-Gough, F. (2004). Using computer assisted qualitative data analysis software: Respecting voices within data management and analysis. In C. Humphrey \& B. Lee (Eds.), The real life guide to accounting research: A behind-the-scenes view of using qualitative research methods, (pp. 373-390). Elsevier Ltd: Netherlands.

Ashby, J., Sadera, W.A., \& McNary, S.W. (2011). Comparing student success between developmental math courses offered online, blended and face-to-face. Journal of Interactive Online Learning, 10(3), 128-140.Azemi, A. (2013, October). Teaching electric circuits using a modified flipped classroom approach. Paper presented at the Frontiers in Education Conference, Oklahoma City, USA.

Baepler, P., Walker, J.D., \& Driessen, M. (2014), It's not about seat time: Blending, flipping and efficiency in active learning classrooms. Computers \& Education, 78, 227-236.

Baker, C. R. \& Logan, L. B. (2006). Using action research to promote increased academic success for educationally disadvantaged students. Global Perspectives on Accounting Education, 3, 1-21.

Beattie, V., Collins, B., \& McInnes, B. (1997). Deep and surface learning: a simple or simplistic dichotomy?. Accounting Education: An International Journal, 6(1), 1-12.

Biggs, J.B. (1987). Student approaches to learning and studying. Hawthorn, Victoria: Australian Council for Educational Research.

Biggs, J.B. (2003). Teaching for quality learning at university. Buckingham: Open University Press.

Bishop, J.L., \& Verleger, M.A. (2013, June). The flipped classroom: A Survey of the research. Paper presented at the $120^{\text {th }}$ American Society of Engineering Education Annual Conference \& Exposition, Atlanta.

Booth, P., Luckett, P., \& Mladenovic, R. (1999). The quality of learning in accounting education: the impact of approaches to learning on academic performance. Accounting Education: An International Journal, 8(4), 277-300.

Boyce, G., Williams, S., Kelly, A., \& Yee, H. (2001). Fostering deep and elaborative learning and generic (soft) skill development: the strategic use of case studies in accounting education. Accounting Education, 9(4), 371-387. 
Brown, C.A., Danvers, K., \& Doran, D.T. (2016). Student perceptions on using guided reading questions to motivate student reading in the flipped classroom. Accounting Education, 25(3), 256-271.

Burke, L.A. \& James, K.E. (2008). Power-point based lectures in business education: An empirical investigation of student-perceived novelty and effectiveness, Business Communication Quarterly, 71(3), 277-296.

Butt, A. (2014). Student views on the use of a flipped classroom approach: Evidence from Australia. Business Education and Accreditation, 6(1), 33-43

Capellatto, G. (2010). Challenges facing accounting education in Australia, AFAANZ, Melbourne. Retrieved from 21 August 2015, http://afaanz.org/.

Chan, D., Leung, R., Gow, L., \& Hu, S. (1989). Approaches to learning of accountancy students some additional evidence. Paper presented at the ASAIHL seminar on University Education in the 1990's, Kuala Lumpur.

Chandler, D. \& Torbert, B. (2003). Transforming inquiry and action. Action Research, 1(2), 133-152.

Chi, M. T. H., \& Wylie, R. (2014). The ICAP Framework: Linking cognitive engagement to active learning outcomes. Educational Psychologist, 49(4), 219-243.

Chiu, P.H.P., \& Cheng, S.H. (2017). Effects of active learning classrooms on student learning: a two-year empirical investigation on student perceptions and academic performance. Higher Education Research \& Development, 36(2), 269-279.

Coghlan, D., \& Brydon-Miller, M. (2014). Introduction. In Coghlan, D., \& Brydon-Miller, M. (Eds.) The SAGE Encyclopedia of Action Research. (pp xxv-xxvi). Retrieved from https://books.google.com.au/books?hl=en\&lr=\&id=hNfSAwAAQBAJ\&oi=fnd\&pg=PP1\&dq $=$ Coghlan+and + Brydon-

Miller\&ots=LnLMYcNVes\&sig=yfsYD31j8S6W3u_UmOVhrduXdb0\#v=onepage\&q=Cogh lan\%20and\%20Brydon-Miller\&f=false.

Cooper, B.J. (2004). The enigma of the Chinese learner. Accounting Education - An International Journal, 13(3), 289-310. 
Cunningham, B. M. (2008). Using action research to improve learning and the classroom learning environment. Issues in Accounting Education, 23(1), 1-30.

Curtis, S. M. (2017). Pathway to reform: developing action research capacity in accounting education. Issues in Accounting Education, 32(3), 51-79.

Davidson, R.A. (2002). Relationship of study approach and exam performance. Journal of Accounting Education, 20(1), 29-44.

De Lange, P., \& Watty, K. (2011). Accounting education at a crossroad in 2010 and challenges facing accounting education in Australia. Accounting Education, 20(6), 625-630.

De Lange, P., Surwardy, T. \& Mavondo, F. (2003). Integrating a virtual learning environment into an introductory accounting course: Determinants of students motivation. Accounting Education, 12(1), 1-14.

De Lange, P., Jackling, B., \& Gut, A. (2006). Accounting graduates' perception of skills emphasis in undergraduate courses: An investigation from two Victorian universities. Accounting and Finance, 46(3), 365-386.

De villiers R. (2010). The incorporation of soft skills into accounting curricula: preparing accounting graduates for their unpredictable futures, Meditari Accountancy Research, 18(2), $1-22$.

Department of Education and Training (2017). Higher Education all student enrolment tables, Australian Government Department of Education and Training. Retrieved 27 March 2018 from https://www.education.gov.au/higher-education-statistics?page=4\&resource=

Doran, J., Healy, M., McCutcheon, M. \& O’Callaghan, S. (2011). Adapting case-based teaching to large class settings: an action research approach. Accounting Education: an international journal, 20(3), 245-263.

Du, X., \& Taylor, S. (2013, December). Flipped classroom in a first year management accounting unit: a case study. Paper presented at the Electric Dreams: 30th Ascilite Conference, Macquarie University, Sydney.

Duff, A. (2004). Understanding academic performance and progression of first-year accounting and business economics undergraduates: the role of approaches to learning and prior academic achievement. Accounting Education: An International journal, 13(4), 409-430. 
Eley, M.G. (1992). Differential adoption of study approaches within stakeholder students. Higher Education, 23, 231-254.

English, L., Luckett, P., \& Mladenovic, R. (2004). Encouraging a deep approach to learning through curriculum design, Accounting Education: An International Journal, 13(3), 461-488.

Evans, E., Burritt, R., \& Guthrie, J. (Eds.) (2010). Institute of Chartered Accountants in Australia (ICAA) (2010). Accounting Education at a Crossroad in 2010. Sydney: ICAA; Adelaide: Centre for Accounting, Governance and Sustainability.

Findlay-Thompson, S., \& Mombourquette, P. (2014). Evaluation of a flipped classroom in an undergraduate business course. Business Education \& Accreditation, 6(1), 63-71.

Gleason, B. L., Peeters, M. J., Resman, B. H., Karr, S., McBane, S., Kelley, K., Thomas, T., \& Denetclaw, T.H. (2011). An active-learning strategies primer for achieving ability-based educational outcomes. American Journal of Pharmaceutical Education, 75(9).

Gordon, C., \& Debus, R. (2002). Developing deep learning approaches and personal teaching efficacy within a preservice teacher education context. British Journal of Educational Psychology, 72(4), 483-511.

Gow, L., Kember, D., \& Cooper, B. (1994). The teaching context and approaches to study of accountancy students. Issues in Accounting Education, 9(1), 118-130.

Graduate Careers Australia. (2015). Graduate Outlook Survey. Retrieved 2 April 2018 from http://www.graduatecareers.com.au/research/surveys/graduateoutlooksurvey/

Gustavsen, B. (2008). Action research, practical challenges and the formation of theory. Action Research, 6(4), 421-437.

Haidet, P., Morgan, R.O., O’Malley, K., Moran, B.J., \& Richards, B.F. (2004). A controlled trial of active versus passive learning strategies in a large group setting. Advances in Health Sciences Education, 9, 15-27.

Hall, M., Ramsay, A., \& Raven, J. (2004). Changing the learning environment to promote deep learning approaches in first-year accounting students. Accounting Education, 13(4), 489-505.

Hand, L. (1998). Tackling an accounting coursework assignment - action research on the student perspective. Accounting Education, 7(4), 305-323. 
Hand, L. \& Rowe, M. (2001). Evaluation of student feedback. Accounting Education, 10(2), 147-160.

Hand, L., Sanderson, P. \& O’Neil, M. (1996). Fostering deep and active learning through assessment. Accounting Education, 5(1), 103-119.

Hazelton, J. \& Haigh, M. (2010). Incorporating sustainability into accounting curricula: lessons learnt from an action research study. Accounting Education: an international journal, 19(1-2), 159-178.

Jackling, B. (2005a). Perceptions of the learning context and learning approaches: Implications for quality learning outcomes in accounting, Accounting Education: an international journal, 14(3), 271-291.

Jackling, B. (2005b). Analysis of the learning context, perceptions of the learning environment and approaches to learning accounting: a longitudinal study, Accounting and Finance, 45, 597612.

Jackling, B., \& De Lange, P. (2009). Do accounting graduates' skills meet the expectations of employers? A matter of convergence or divergence. Accounting Education: An International Journal, 18(4-5), 369-385.

James, A.J., Chin, K.H., \& Williams, B.R. (2014), Using the flipped classroom to improve student engagement and to prepare graduates to meet maritime industry requirement: a focus on maritime education. WMU Journal of Maritime Affairs, 13(2), 331-343.

Kelly, M., Davey, H. \& Haigh, N. (2000). Use of action-research methodology in the development of accounting education. Accounting Educators' Journal, XII, 1-11.

Kemmis, S. (2009). Action research as a practice-based practice. Educational Action Research, 17(3), 463-474.

Kern, B. (2002). Enhancing accounting students' problem-solving skills: the use of a hands-on conceptual model in an active learning environment. Accounting Education, 11(3), 235-256.

Kim, M.K., Kim, S.M., Khera, O., \& Getman, J. (2014). The experience of three flipped classrooms in an urban university: an exploration of design principles. Internet \& Higher Education, 22, 37-50. 
Kong, S. C. (2014). Developing information literacy and critical thinking skills through domain knowledge learning in digital classrooms: An experience of practicing flipped classroom strategy. Computers \& Education, 78, 160-173.

Laird, T.F.N., Shoup, R., Kuh, G.D., \& Schwarz, M.J. (2008). The effects of discipline on deep approaches to student learning and outcomes. Research in Higher Education, 49, 469-494.

Lento, C. (2016). Promoting active learning in introductory financial accounting through the flipped classroom design. Journal of Applied Research in Higher Education, 8(1), 72-87.

Leveson, L. (2004). Encouraging better learning through better teaching: a study of approaches to teaching in accounting. Accounting Education: An International Journal, 13(4), 529-548.

Marcey, D. J., \& Brint, M. E. (2012, November). Transforming an undergraduate biology course through cinematic lectures and inverted classes: a preliminary assessment of the CLIC model of the flipped classroom. Paper presented at the NABT Biology Education Research Symposium, Dallas, Texas.

Mason, G., Shuman, T. R., \& Cook, K. E. (2013, June). Inverting (flipping) classrooms advantages and challenges. Paper presented at the $120^{\text {th }}$ ASEE Annual Conference \& Exposition, Atlanta, Georgia.

McGrath, D. \& Murphy, D. (2016). Understanding accounting as a career: an immersion work experience for students making career decisions. Accounting Education, 25(1), 57-87.

Milman, N. (2012). The flipped classroom strategy: what is it and how can it best be used. Distance Learning, 9(3), 85-87.

Mladenovic, R. (2000). An investigation into ways of challenging introductory accounting students' negative perceptions of accounting. Accounting Education, 9(2), 135-155.

Murray, D., Koziniec, T., \& McGill, T. (2015, January). Student perception offlipped learning. Paper presented at the $17^{\text {th }}$ Australasian Computer Education Conference, Sydney, Australia.

Norton, A. (2016). Mapping Australian Higher Education 2016. Grattan Institute.

Nunnaly, J. (1978). Psychometric Theory. New York: McGraw-Hill.

O’Connor, C., Mortimer, D., \& Bond, S. (2011). Blended learning: Issues, benefits and challenges. International Journal of Employment studies, 19(2), 62-82.

O'Dwyer, B. (2004). Qualitative data analysis: Illuminating a process for transforming a 'Messy' but 'Attractive' 'Nuisance'. In C. Humphrey and B. Lee (Eds.), The real life guide to 
accounting research: A behind-the-scenes view of using qualitative research methods, (pp. 391-408). Netherlands: Elsevier Ltd.

O'Flaherty, J., \& Phillips, C. (2015). The use of flipped classrooms in higher education: A scoping review, Internet and Higher Education, 25, 85-95.

Paisey, C. \& Paisey, N. J. (2003). Developing research awareness in students: an action research project explored. Accounting Education, 12(3), 283-302.

Paisey, C. \& Paisey, N. (2005). Improving accounting education though the use of action research. Journal of Accounting Education, 23, 1-19.

Pierce, R., \& Fox, M. (2012). Vod-casts and active-learning exercises in a "flipped classroom" model of a renal pharmacotherapy module. American Journal of Pharmaceutical Education, $76(10)$.

Ramsden, P. (1992). Learning to teach in Higher Education. London: Routledge.

Richardson, M., Abraham, C., \& Bond, R. (2012). Psychological correlates of university students' academic performance: A systematic review and meta-analysis, Psychological Bulletin, 138(2), 353-387.

Sharma, D.S. (1997). Accounting students' learning conceptions, approaches to learning, and the influence of the learning-teaching context on approaches to learning. Accounting Education: An International Journal, 6(2),125-146.

Shauki, E.R., \& Benzie, H. (2017). Meeting threshold learning standards through selfmanagement in group oral presentations: observations on accounting postgraduate students. Accounting Education, 26(4), 358-376.

Somekh, B. \& Zeichner, K. (2009). Action research for education reform: remodelling action research theories and practices in local contexts. Educational Action Research, 17(1), 5-21.

Strayer, J.F. (2012). How learning in an inverted classroom influences cooperation, innovation and task orientation. Learning Environment Research, 15, 171-193.

Tamin, R.M., Bernard, R.M., Borokhovski, E., Abrami, P.C., \& Schmid, R.F. (2011). What forty years of research says about the impact of technology on learning. Review of Educational Research, 81(1), 4-28. 
Toto, R., \& Nguyen, H. (2009). Flipping the work design in an industrial engineering course. Paper presented at the $39^{\text {th }}$ ASEE/IEEE Frontiers in Education Conference, San Antonio, Texas, USA.

White, P.J., Larson, I., Styles, K., Yuriev, E., Evans, D.R., Rangachari, P.K., ... Naidu, S. (2016). Adopting and active learning approach to teaching in a research-intensive higher education context transformed staff teaching attitudes and behaviours. Higher Education Research \& Development, 35(3), 619-633.

Zhu, W., \& Xie, W. (2018). Evaluating instructional effects of flipped classroom in university: A case study on electronic business course. International Journal of Distance Education Technologies, 16(1), 45-55. 